\title{
The effect of intravenous dexamethasone on pain relief, blood glucose and lactate levels after hip arthroplasty
}

\author{
Iveta Golubovska $^{1,2}$, Natalija Buraka ${ }^{1}$, Aleksejs Miscuks ${ }^{1,2}$, Lauris Repsa ${ }^{1,3,}$,Sergejs Zadoroznijs ${ }^{1,2}$
}

traumatologisas 1 Faculty of Medicine, University of Latvia

UN ORTOPEDIJAS 2 Hospital of Traumatology and Orthopaedics

SLIMNICA $\quad 3$ Faculty of medicine Riga Stradins University

\section{Background and aims}

Dexamethasone provides antiinflammatory and analgesic effect, but induces hyperglycemia and may increase serum lactate. The aim was to determine the effect of dexamethasone on analgesia, blood glucose and lactate level after hip arthroplasty.

\section{Methods}

1)Prospective randomized pilot study includes 50 patients undergoing hip arthroplasty.

2) SA and multimodal analgesia, Sol. Morphini $10 \mathrm{mg} \mathrm{s} / \mathrm{c}$ as a rescue medication. 3)The experimental group received $i / v$ dexamethasone $8 \mathrm{mg}$ peroperatively and 4 $\mathrm{mg} \mathrm{i} / \mathrm{v}$ at 6 and 12 hours after the first dose. 4)The control group didn't receive glucocorticoids

5)Blood glucose and lactate levels were measured before the surgery and after at 18.00 and 6.00 on the $1^{\text {st }}$ post operative day (POD1) .

6)Patients filled in a pain questionnaire (VAS scale) for the perioperative period.

7) The amount of rescue analgesic were counted for a period $24 \mathrm{~h}$ after surgery

8) Data were processed using SPSS program.

Figure 1: pain in rest

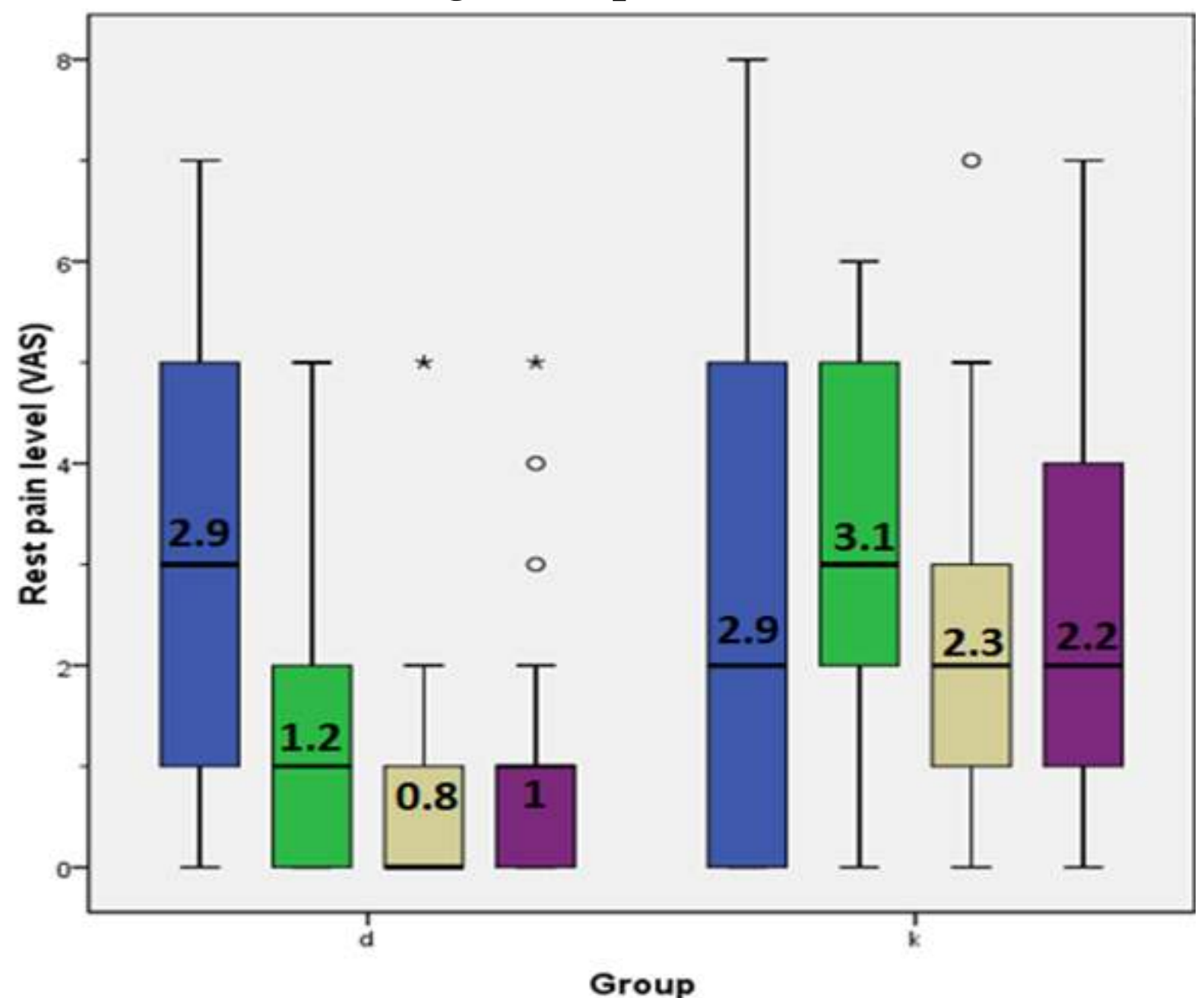

\section{Conclusions}

1)dexamethasone provides excellent analgesic effect

2)serum glucose and lactate do not reach recovery affecting level during perioperative period after hip replacement.

3)dexamenthasone doesn't allow the use of lower resque medication dose.

\section{Results}

- $\quad$ Pain level in rest in the experimental and control group accordingly was 1.2 and $3.1(\mathrm{p}<0.001)$ at $18: 00 ; 0.8$ and $2.3(\mathrm{p}<0.001)$ at $6: 00$ on POD1; 1 and 2.2 $(\mathrm{p}<0.015)$ at 18:00 on POD1.(fig.1)

- $\quad$ Pain level on movement in the experimental and control group accordingly was -2.0 and $3.9(\mathrm{p}<0.001)$ at $18: 00 ; 1.8$ and $4.2(\mathrm{p}<0.001)$ at $6: 00 ; 2.2$ and 3.8 $(\mathrm{p}<0,001)$ at 18:00 on POD1. (fig.2)

- There is no significant differences in requirement of rescue analgesic between these groups.
Table 1: Glucose level variation during perioperative period ( $\mathrm{mmol} / \mathrm{l})$

\begin{tabular}{|c|c|c|c|}
\hline & Start & 18:00 & $6: 00$ \\
\hline $\begin{array}{l}\text { Control } \\
\text { group }\end{array}$ & 5.4 & 6.4 & 5.8 \\
\hline $\begin{array}{l}\text { Dexone } \\
\text { group }\end{array}$ & 5.5 & 8.3 & 7.5 \\
\hline $\begin{array}{c}\text { CI } \\
\text { of the } \\
\text { difference }\end{array}$ & $\begin{array}{l}0.19 \\
0.52\end{array}$ & $\begin{array}{l}1.08 \\
2.66\end{array}$ & $\begin{array}{l}1.16 \\
2.35\end{array}$ \\
\hline P-value & - & $<0.001$ & $<0.001$ \\
\hline
\end{tabular}

Table 2 : Lactate level variation during perioperative period ( $\mathrm{mmol} / \mathrm{l})$

\begin{tabular}{|c|c|c|c|}
\hline & Start & 18:00 & $6: 00$ \\
\hline $\begin{array}{l}\text { Control } \\
\text { group }\end{array}$ & 1.57 & 1.08 & 1.54 \\
\hline $\begin{array}{c}\text { Dexone } \\
\text { group }\end{array}$ & 1.02 & 1.32 & 1.9 \\
\hline $\begin{array}{c}\text { CI } \\
\text { of the } \\
\text { difference }\end{array}$ & $\begin{array}{l}-1.03 \\
-0.07\end{array}$ & $\begin{array}{l}-0,3 ; \\
0.77\end{array}$ & $\begin{array}{l}-0.2 \\
0.91\end{array}$ \\
\hline P-value & - & 0.38 & 0.2 \\
\hline
\end{tabular}

\section{Perioperative pain level}

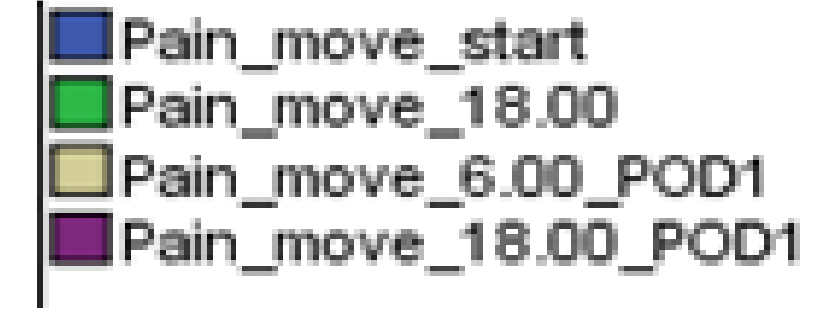

$\mathrm{d}$ - dexamethasone group

$\mathrm{k}$ - control group
Figure 2: pain on movement

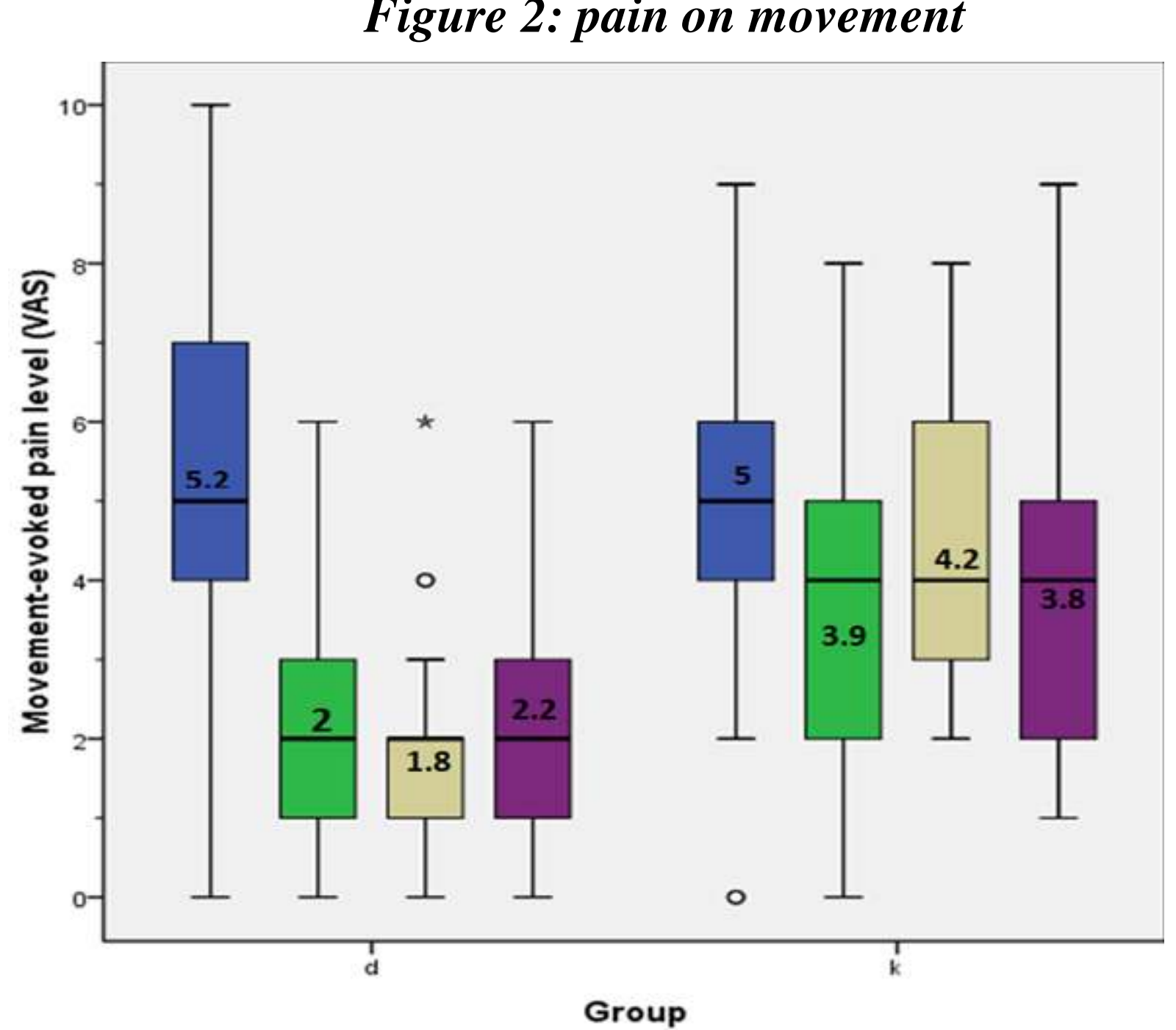

References

1)Xiaofei Li, Gang Xu, Wenjin Xie, Shengan Ma «The efficacy and safety of dexamethasone for pain management after total knee arthroplasty. A sistemic review and meta-analysis». International Journal of surgery, 2018, p. 65-71

2)K. Mizen, J. Woodman, S.R. Boysen, C. Wagg, P. Greco-Otto, R. Léguillette, and M.-F.Roy «Effect of Dexamethasone on Resting Blood Lactate Concentrations in Horses», Journal of Veterinary Internal Medicine published by Wiley Periodicals, 2017 Jan-Fab; 31(1): p.164-169; Published online 2016 Dec 25.

3) Gritsenko Karina, Khmelevsky Yury, Kaye Alan David «Multimodal therapy in perioperative analgesia», «Best practise\&Research Clinical Anaesthesiology», 2014, p. 59-79. 